\title{
FAKTOR-FAKTOR PENILAIAN KINERJA KEUANGAN PADA PT. SINAR RODA UTAMA
}

\author{
Putri Ratna Sari \\ Alumni Program Akuntansi S1 \\ Sekolah Tinggi Ilmu Ekonomi Bisnis Indonesia, Jakarta \\ Muhammad Ichwan Hamzah \\ Dosen STIE Bisnis Indonesia, Jakarta \\ Sofia Maulida \\ Dosen STIE Bisnis Indonesia, Jakarta
}

\begin{abstract}
The purpose of this study is to find out how financial ratio analysis to assess the financial performance of PT. Main Wheel Rays in terms of liquidity ratios, solvency ratios, and profitability ratios using secondary data. The research method used is descriptive quantitative and independent variables, namely the company's financial performance measured by several sub variables including liquidity ratios, solvency ratios, and profitability ratios. The results of the research are the analysis of the ratio of liquidity, solvency, and profitability to assess the financial performance of PT. Main Wheel Rays seen from the liquidity ratio of the company's financial performance are in good condition, but too much cash is not used. When viewed from the solvency ratio, the company's financial performance is in a bad condition, because the debt ratio continues to increase. When viewed from the profitability ratio, the company's financial performance is in good condition, but must continue to increase profits.

Keywords: Financial Report, Liquidity Ratio, Solvability Ratio, Profitability Ratio, Financial Performance.
\end{abstract}

\begin{abstract}
Abstrak: Tujuan penelitian ini untuk mengetahui bagaimana analisis rasio keuangan untuk menilai kinerja keuangan PT. Sinar Roda Utama ditinjau dari rasio likuiditas, rasio solvabilitas, dan rasio profitabilitas dengan menggunakan data sekunder. Metode penelitian yang digunakan adalah deskriptif kuantitatif dan variabel bebas yaitu kinerja keuangan perusahaan diukur dengan beberapa sub variabel diantaranya rasio likuiditas, rasio solvabilitas, dan rasio profitabilitas. Hasil penelitian analisis rasio likuiditas, solvabilitas, dan profitabilitas untuk menilai kinerja keuangan PT. Sinar Roda Utama dilihat dari rasio likuiditas kinerja keuangan perusahaan dalam keadaan baik, tetapi terlalu banyak kas yang tidak digunakan. Bila dilihat dari rasio solvabilitas, kinerja keuangan perusahaan dalam keadaan kurang baik, karena rasio utang terus meningkat. Bila dilihat dari rasio profitabilitas, kinerja keuangan perusahaan dalam keadaan baik, tetapi harus tetap meningkatkan profitnya.

Kata Kunci: Laporan Keuangan, Rasio Likuiditas, Rasio Solvabilitas, Rasio Profitabilitas, Kinerja Keuangan.
\end{abstract}




\section{Pendahuluan}

Persaingan antar perusahaan maupun antar negara tersebut berlangsung secara bebas dan ketat karena banyak bermunculan perusahaan asing di dalam negeri yang disebabkan oleh semakin tipisnya batas antar negara. Kondisi seperti ini menyebabkan perusahaan harus mampu meningkatkan kinerjanya. Kinerja suatu perusahaan sangat tergantung pada bagaimana manajemen mengelola keuangan dan melaksanakan aktivitas perusahaan tersebut. Oleh karena itu, pihak manajemen dituntut untuk mampu meningkatkan kemampuan dan profesionalismenya. Hal ini bertujuan agar manajemen perusahaan mampu mencapai tujuan-tujuan perusahaan yang telah ditetapkan sebelumnya. Kinerja yang baik akan dapat membantu manajemen dalam pencapaian tujuan perusahaan. Semakin tinggi kinerja perusahaan, maka akan semakin baik pula nilai perusahaan di mata investor. Selain itu perkembangan teknologi yang terus meningkat dengan pesat menyebabkan semakin diperlukannya keahlian dalam menganalisis laporan keuangan. Untuk itu manajer dituntut memilih informasi dalam jaringan yang luas untuk mengetahui kondisi perusahaan saat ini maupun perkiraan kondisi dimasa yang akan datang.

Efektivitas dan efesiensi suatu perusahaan dalam menjalankan operasinya ditentukan oleh kemampuan perusahaan dalam memperoleh profitabilitas dan aktivitas dalam perusahaan.Untuk mendukung kelangsungan dan peningkatan usaha, maka perusahaan perlu menganalisis laporan keuangan agar dapat memperoleh informasi tentang posisi keuangan perusahaan yang bersangkutan. Dengan menganalisis laporan keuangan akan membantu pihak-pihak yang berkepentingan dalam memilih dan mengevaluasi informasi, sehingga setiap perusahaan dituntut untuk dapat meningkatkan daya saingnya masing-masing. Laporan keuangan merupakan sumber informasi sehubungan dengan posisi keuangan dan kinerja keuangan perusahaan. Salah satu cara untuk menilai kinerja keuangan pada saat ini maupun prospek usaha yang akan datang adalah dengan cara menganalisis laporan keuangan perusahaan yang terdiri dari neraca dan laporan laba rugi. Alat analisis yang sering digunakan untuk mengetahui kinerja keuangan adalah rasio keuangan. Rasio merupakan teknik analisa laporan keuangan yang sering digunakan. Rasio merupakan alat analisis yang dapat memberikan jalan keluar dan menggambarkan gejala-gejala yang tampak pada suatu laporan keuangan.

Ada beberapa kelompok rasio yang sering dipakai dalam menganalisa keuangan perusahaan yaitu Likuiditas, Solvabilitas, dan Profitabilitas. Analisis rasio keuangan bersifat menyeluruh karena mencakup tingkat efisiensi perusahaan dalam penggunaan aktivanya dan dapat mengukur tingkat keuntungan yang dihasilkan perusahaan. Likuiditas dapat memberikan gambaran mengenai kemampuan perusahaan dalam memenuhi kewajiban jangka pendek. Solvabilitas dapat memberikan gambaran kemampuan perusahaan dalam memenuhi semua kewajiban keuangannya. Profitabilitas dapat menilai perkembangan laba dari tahun ke tahun. Data keuangan tersebut dianalisis lebih lanjut sehingga akan diperoleh informasi yang dapat mendukung keputusan yang dibuat. Laporan keuangan ini harus menggambarkan semua data keuangan yang relevan dan telah ditetapkan prosedurnya sehingga laporan keuangan dapat diperbandingkan agar tingkat akurasi analisis dapat di pertanggungjawabkan.

PT. Sinar Roda Utama berdiri sejak tahun 1989 dengan bergerak dalam bidang distribusi alatalat kesehatan yang telah memiliki pengalaman lebih dari 26 tahun, diantaranya dalam pelayanan tindakan hemodialisa atau pelayanan cuci darah bagi pasien gagal ginjal dan juga sebagai mitra dari PT. Askes Indonesia \& Pasien Jamkesmas yang saat ini diganti menjadi Badan Penyelenggara Jaminan Sosial Kesehatan (BPJS Kesehatan) maupun Pasien Umum di Rumah Sakit. Berdasarkan uraian di atas maka penulis mengangkat judul penilitian yaitu: "Analisis Rasio Likuiditas, Solvabilitas, Dan Profitabilitas Untuk Menilai Kinerja Keuangan Pada PT. Sinar Roda Utama. 


\section{Landasan Teori}

2.1. Akuntansi

Komite Terminologi AICPA (The Committee on Terminology of the American Institute of Certified Public Accountants) memberikan dua definisi akuntansi dari sudut pandang berbeda yang dikutip Belkaoui (2010:66) sebagai berikut:

1. Akuntansi merupakan seni pencatatan, penggolongan, dan peringkasan transaksi dan kejadian yang bersifat keuangan dengan cara yang berdaya guna dan dalam bentuk satuan uang, dan penginterpretasian hasil proses tersebut.

2. Akuntansi sebagai aktifitas jasa. Fungsinya untuk menyediakan informasi kuantitatif, terutama bersifat keuangan tentang entitas ekonomi yang diperkirakan bermanfaat dalam pembuatan keputusan-keputusan ekonomi dalam membuat pilihan diantara alternatif tindakan yang ada.

\subsection{Laporan Keuangan}

Menurut Munawir (2004:2) "Laporan keuangan adalah hasil dari proses akuntansi yang dapat digunakan sebagai alat untuk berkomunikasi antara data keuangan atau aktivitas suatu perusahaan dengan pihak-pihak yang berkepentingan dengan dana atau aktivitas perusahaan tersebut". Rahardjo (2002:1) menjelaskan bahwa "Laporan keuangan adalah laporan pertanggungjawaban manajer atau pimpinan perusahaan atas pengelolaan perusahaan yang dipercayakan kepada pihakpihak yang memiliki kepentingan (Stakeholders) di luar perusahaan seperti pemilik perusahaan, pemerintah, kreditor dan pihak lainnya." Menurut Soemarso (2009:130) "Laporan keuangan adalah media komunikasi yang biasa digunakan perusahaan untuk pihak luar. Di dalamnya tercantum sebagian besar informasi keuangan yang bermanfaat sebagai bahan pertimbangan dalam pengambilan keputusan." Selanjutnya menurut Munawir (2004:5) "Laporan keuangan pada perusahaan merupakan hasil akhir dari kegiatan akuntansi (siklus akuntansi) yang mencerminkan kondisi keuangan dan hasil operasi perusahaan." Laporan keuangan sebagai laporan yang menggambarkan kondisi keuangan dan hasil usaha suatu perusahaan pada saat tertentu atau jangka waktu tertentu. Laporan ini terdiri dari neraca, laporan laba rugi, laporan arus kas dan laporan perubahan posisi keuangan (Harahap, 2012).

\subsection{Laporan Neraca}

Rahardjo (2002) menjelaskan bahwa "Neraca adalah laporan posisi keuangan perusahaan pada suatu waktu tertentu. Sisi kiri neraca menunjukkan aktiva perusahaan, sedangkan sisi kanan neraca menunjukkan kewajiban dan ekuitas, atau klaim terhadap aktiva tersebut."

1. Aktiva
a. Aktiva Lancar
b. Investasi
c. Aktiva Tetap
d. Aktiva Tak Berwujud
e. Aktiva lain-lain

2. Kewajiban/Utang

Hutang perusahaan masa kini yang timbul dari peristiwa masa lalu, penyelesaiannya diharapkan mengakibatkan arus keluar dari sumber daya perusahaan yang mengandung manfaat ekonomi. Kewajiban terdiri dari kewajiban lancar, kewajiban jangka panjang dan kewajiban lain-lain."

3. Modal

Hak pemilik perusahaan atas kekayaan (aktiva) perusahaan. Besarnya hak pemilik sama dengan aktiva bersih perusahaan, yaitu selisih antara aktiva dan kewajiban. Dengan demikian jumlah modal merupakan sisa yaitu hak atas sisa aktiva setelah dikurangi kewajiban kepada para kreditur. 


\subsubsection{Bentuk Penyajian Neraca}

Menurut Sugiono dan Untung (2008:14) "Terdapat dua bentuk neraca yang umum digunakan yaitu:

1. Bentuk rekening (accountform)

Dalam bentuk ini aktiva ditempatkan di sebelah kiri, sedangkan kewajiban dan modal ditempatkan di sebelah kanan.

2. Bentuk neraca laporan (reportform)

Dalam bentuk ini aktiva ditempatkan pada bagian atas, sedangkan kewajiban dan modal ditempatkan di bawahnya secara vertikal.

\subsection{Pengertian Laporan Rugi Laba}

Astuti (2002:17) menjelaskan bahwa "Laporan Rugi/Laba adalah laporan yang mengikhtisarkan pendapatan dan beban perusahaan selama periode akuntansi tertentu, yang umumnya setiap kuartal atau setiap tahun." Sedangkan menurut Jusup (2011:23) menerangkan bahwa "Laporan laba rugi disusun dengan maksud untuk menggambarkan hasil operasi perusahaan dalam suatu periode waktu tertentu. Isi dari laporan rugi-laba terdiri atas tiga komponen pokok, yaitu pendapatan, biaya dan laba atau rugi. Pendapatan adalah aliran penerimaan kas atau harta lain yang diterima dari konsumen sebagai hasil penjualan barang atau pemberian jasa.

\subsection{Laporan Arus Kas}

Nurfitriani (2005:10) menerangkan bahwa "Laporan arus kas melaporkan arus kas selama periode tertentu dan diklasifikasikan menurut aktivitas operasi, investasi dan pendanaan. Klasifikasi tersebut memberikan informasi yang memungkinkan pengguna laporan keuangan untuk menilai pengaruh aktivitas-aktivitas tersebut terhadap posisi keuangan perusahaan serta terhadap jumlah kas dan setara kas."

\subsection{Pengertian Analisis Laporan Keuangan}

Menurut Harahap (2012:190) "Analisis laporan keuangan adalah menguraikan pos-pos laporan keuangan menjadi unit informasi yang lebih kecil dan melihat hubungannya yang bersifat signifikan atau yang mempunyai makna antara satu dengan yang lain baik antara data kuantitatif maupun data non kuantitatif dengan tujuan untuk mengetahui kondisi keuangan lebih dalam yang sangat penting dalam proses menghasilkan keputusan yang tepat." Analisis laporan keuangan mengurangi ketergantungan pada firasat, tebakan dan intuisi dalam pengambilan keputusan.

\subsubsection{Tujuan Analisis Laporan Keuangan}

Menurut Sugiono dan Untung (2008:13) "Dalam laporan keuangan memiliki beberapa tujuan yaitu sebagai berikut:

1. Screening

2. Understanding (pemahaman)

3. Forecasting (peramalan)

4. Diagnosis (diagnosa)

5. Evaluation (Evaluasi)

\subsubsection{Rasio Keuangan}

Rasio keuangan merupakan satu dari beberapa cara yang dapat digunakan dalam menganalisis keadaan keuangan perusahaan, hal ini yang sangat umum dilakukan di mana hasilnya akan memberikan pengukuran relative dari operasi perusahaan (Rahardjo, 2002). Menurut Sutrisno (2009:215), beberapa jenis analisis rasio keuangan yang digunakan untuk menilai kinerja financial antara lain: 
1. Rasio Likuiditas

2. Rasio Solvabilitas

3. Rasio Profitabilitas

\section{Metodologi Penelitian}

Dalam rangka pengumpulan dan pencarian data yang berhubungan dengan objek penelitian. Penelitian dilaksanakan pada PT. Sinar Roda Utama yang bertempat di Jl. Panjang No.12, Kebon Jeruk, Jakarta Barat 11530. Waktu penelitian dilakukan pada bulan April 2017 sampai dengan selesai. Dalam menganalisis masalah penulis menggunakan metode deskriptif kuantitatif, yaitu memberikan gambaran fakta-fakta yang diperoleh dari hasil kegiatan penelitian lapangan tentang kegiatan objek penelitian serta menganalisis data dengan cara mengumpulkan data dan kemudian dibandingkan dengan teori yang relevan dengan masalah yang dibahas untuk diambil kesimpulan serta saran kepada perusahaan. Analisis data kuantitatif bersifat induktif, artinya suatu analisis berdasarkan data yang diperoleh kemudian dikembangkan berdasarkan pola tertentu atau menjadi hipotesis. Analisis kuantitatif dari suatu peristiwa dapat dilihat dari tiga hal:

1. Hasil pengamatan, yang berupa uraian rinci tentang situasi, kejadian, interaksi, dan tingkah laku yang di amati dilapangan

2. Hasil pembicaraan, yaitu kutipan langsung dari orang-orang yang berpengalaman, sikap, keyakinan, dan pemikiran mereka dalam kesempatan wawancara

3. Bahan tertulis atau dokumen, surat-menyurat, rekaman dan kasus sejarah

$$
\begin{aligned}
& \text { 4. Analisa dan Pembahasan } \\
& \text { 4.1. Analisis Data } \\
& \text { 4.1.1. Perhitungan Rasio Likuiditas } \\
& \text { Current Ratio }=\text { Aktiva Lancar } \times 100 \% \\
& \text { Hutang Lancar } \\
& 2013=\underline{192.152 .619} \times 100 \%=104,92 \% \\
& 813.14 .613 \\
& 2014=\underline{326.243 .695} \times 100 \%=505,92 \% \\
& 64.484 .971 \\
& 2015=\underline{323.137 .765} \times 100 \%=481,18 \% \\
& 67.155 .332 \\
& 2016=\underline{378.025 .198} \times 100 \%=306,02 \% \\
& 123.527 .900
\end{aligned}
$$

Quick Ratio= $($ Aktiva Lancar - Persediaan $) \times 100 \%$

$$
\text { Hutang Lancar }
$$

2013

$=(192.152 .619-119.668 .358) \times 100 \%=39,58 \%$

$$
183.143 .613
$$

2014

$=(326.243 .695-109.569 .858) \times 100 \%=336,01 \%$

64.484 .971

2015

$=\underline{(323.137 .765-135.788 .325)} \times 100 \%=278,98 \%$

67.155 .332

2016

$$
=(378.025 .198-147.615 .967) \times 100 \%=186,52 \%
$$

123.527 .900 
$=\frac{\text { Kas }}{\text { Hutang Lancar }} \times 100 \%$

2013

$=\frac{6.107 .134}{183.143 .613} \times 100 \%=3,33 \%$

$2014=\underline{81.604 .263} \times 100 \%=126,55 \%$ 64.484 .971

$2015 \quad=\underline{77.136 .595} \times 100 \%=114,86 \%$

67.155 .332

2016

$=60.487 .294 \times 100 \%=48,97 \%$ 123.527 .900

\subsubsection{Perhitungan Rasio Solvabilitas}

Debt To Total Assets Ratio

$=$ Total Hutang x 100\%

Total Aktiva

2013

$=268.388 .086 \times 100 \%=58,51 \%$

458.690 .770

$2014=467.433 .129 \times 100 \%=66,89 \%$

698.865 .904

$2015=\underline{506.605 .558} \times 100 \%=64,67 \%$

783.346 .730

2016

$$
=\underline{616.060 .202}=100 \%=65,04 \%
$$

Debt To Equity Ratio

$=$ Total Hutang $\times 100 \%$

Total Ekuitas

2013

$=\underline{268.388 .086} \times 100 \%=141,03 \%$

190.302 .684

$2014=\underline{467.433 .129} \times 100 \%=201,97 \%$

231.432 .775

2015

$=506.605 .558 \times 100 \%=183,06 \%$

276.741 .172

2016

$=\underline{616.060 .202} \times 100 \%=186,06 \%$

331.109 .508

4.1.3. Perhitungan Rasio Profitabilitas

Gross Profit Margin

$=($ Penjualan - HPP $) \times 100 \%$

Penjualan

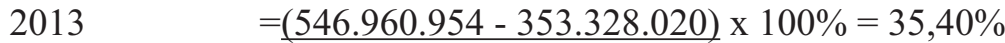

546.960 .954

2014

$=(589.089 .425-432.203 .710) \times 100 \%=26,63 \%$

589.089 .425

2015

$=\underline{(631.342 .874-488.578 .225)} \times 100 \%=22,61 \%$

631.342 .874 
Net Profit Margin

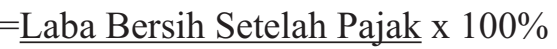
Penjualan

2013

$=\underline{29.595 .892} \times 100 \%=5,41 \%$

546.960 .954

2014

$=\underline{50.453 .108} \times 100 \%=8,57 \%$ 589.089 .425

$2015=\underline{55.663 .929} \times 100 \%=8,82 \%$ 631.342 .874

$2016=\underline{59.365 .690} \times 100 \%=8,73 \%$ 679.939 .490

\section{Rentabilitas Ekonomi}

$=$ Laba Bersih Sebelum Pajak x 100\% Total Aktiva

2013

$=\underline{44.242 .884} \times 100 \%=9,65 \%$ 458.690 .770

$2014=\underline{65.928 .867 \times 100 \%=9,43 \%}$ 698.865 .904

2015

$=\underline{64.584 .701} \times 100 \%=8,24 \%$ 783.346 .730

$2016=\underline{66.027 .791} \times 100 \%=6,97 \%$ 947.169 .710

ROI $=$ Laba Bersih Setelah Pajak x 100\% Total Aktiva

2013

$=\underline{29.595 .892} \times 100 \%=6,45 \%$ 458.690 .770

$2014=\underline{50.453 .108} \times 100 \%=7,22 \%$ 698.865 .904

$2015=\underline{=55.663 .929} \times 100 \%=7,11 \%$ 783.346 .7302016 $=\underline{59.365 .690} \times 100 \%=6,27 \%$ 947.169 .710

ROE $=$ Laba Bersih Setelah Pajak x 100\% Ekuitas

$2013=\underline{29.595 .892} \times 100 \%=15,55 \%$ 190.302 .684

$2014=\underline{50.453 .108} \times 100 \%=21,80 \%$ 231.432 .775

$2015=\underline{55.663 .929} \times 100 \%=20,11 \%$ 276.741 .172

$2016=59.365 .690 \times 100 \%=17,93 \%$ 331.109 .508 
ROA

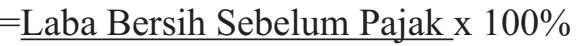

Total Aktiva

2013

$=\underline{44.242 .884} \times 100 \%=9,65 \%$

458.690 .770

2014

$=\underline{65.928 .867} \times 100 \%=9,43 \%$

698.865 .904

2015

$=\underline{64.584 .701} \times 100 \%=8,24 \%$

783.346 .730

2016

$$
=\underline{66.027 .791} \times 100 \%=6,97 \%
$$

\subsection{Pembahasan}

Dari hasil pembahasan di atas, maka dapat dapat dibuat analisis sebagai berikut:

Tabel 4.1

Hasil Rasio Keuangan PT Sinar Roda Utama

\begin{tabular}{|l|c|c|c|c|}
\hline & 2013 & 2014 & 2015 & 2016 \\
\hline Rasio Likuiditas & & & & \\
\hline Current Ratio & $104,92 \%$ & $505,92 \%$ & $481,18 \%$ & $306,02 \%$ \\
\hline Quick Ratio & $39,58 \%$ & $336,01 \%$ & $278,98 \%$ & $186,52 \%$ \\
\hline Cash Ratio & $3,33 \%$ & $126,55 \%$ & $114,86 \%$ & $48,97 \%$ \\
\hline $\begin{array}{l}\text { Rasio } \\
\text { Solvabilitas }\end{array}$ & & & & \\
\hline $\begin{array}{l}\text { Debt To Total } \\
\text { Assets Ratio }\end{array}$ & $58,51 \%$ & $66,88 \%$ & $64,67 \%$ & $65,04 \%$ \\
\hline $\begin{array}{l}\text { Debt To Equity } \\
\text { Ratio }\end{array}$ & $141,03 \%$ & $201,97 \%$ & $183,06 \%$ & $186,06 \%$ \\
\hline $\begin{array}{l}\text { Rasio } \\
\text { Profitabilitas }\end{array}$ & $35,40 \%$ & $26,63 \%$ & $22,61 \%$ & $21,38 \%$ \\
\hline $\begin{array}{l}\text { Gross Profit } \\
\text { Margin }\end{array}$ & $5,41 \%$ & $8,56 \%$ & $8,82 \%$ & $8,73 \%$ \\
\hline $\begin{array}{l}\text { Net Profit } \\
\text { Margin }\end{array}$ & $9,65 \%$ & $9,43 \%$ & $8,24 \%$ & $6,97 \%$ \\
\hline $\begin{array}{l}\text { Rentabilitas } \\
\text { Ekonomi }\end{array}$ & $6,45 \%$ & $7,22 \%$ & $7,11 \%$ & $6,27 \%$ \\
\hline ROI & $15,55 \%$ & $21,80 \%$ & $20,11 \%$ & $17,93 \%$ \\
\hline ROE & $9,65 \%$ & $9,43 \%$ & $8,24 \%$ & $6,97 \%$ \\
\hline ROA & & & & \\
\hline
\end{tabular}

Sumber: Data yang diolah

Untuk rasio likuiditas, selama tahun 2013-2016 PT. Sinar Roda Utama menunjukkan likuiditas yang baik karena bila dilihat dari keseluruhan rasio yang dihasilkan sangat besar dan paling rendah di tahun 2013 sebesar 3,33\% , dimana ditahun tersebut perusahaan tidak mampu membayar kewajiban lancarnya, selanjutnya ditahun-tahun berikutnya perusahaan sudah mengalami kemajuan. Jika dilihat dari current ratio dapat diketahui pada tahun 2013 current ratio sebesar 104,92\%, pada tahun 2014 current ratio meningkat menjadi 505,92\%, pada tahun 2015 current ratio turun menjadi 481,18\%, dan pada tahun 2016 current ratio kembali turun menjadi 306,02\%. Rasio seperti ini sangat baik bagi posisi keuangan perusahaan, namun kurang efisien karena masih banyak aktiva yang tidak digunakan. Untuk rasio solvabilitas, selama tahun 2013-2016 menunjukkan hasil yang kurang memuaskan. rasio solvabilitas PT. Sinar Roda Utama mengalami masa baik pada tahun 2014 dimana perbandingan hutang dengan aktiva ataupun hutang dengan modal sangat sangat kecil, yaitu sebesar 66,88\% untuk Debt To Assetss Ratio, hal ini menunjukkan bahwa pada tahun tersebut nilai 
aktiva lebih besar daripada utang dan 201,97\% untuk Debt To Equity Ratio. Pada tahun-tahun berikutnya rasio hutang perusahaan mulai meninggi tapi masih berada ditingkat yang bagus. Sehingga berdasarkan data tersebut di atas, kinerja keuangan PT. Sinar Roda Utama dalam keadaan kurang baik. Hal ini terlihat dari besarnya rasio hutang terhadap modal yang artinya perusahaan ini tergantung kepada hutang perusahaan. Untuk rasio profitabilitas, selama tahun 2013-2016 menunjukkan hasil yang baik karena penjualan yang dihasilkan terus meningkat setiap tahunnya dan profitabilitasnya cukup baik karena rasio yang dihasilkan cukup tinggi di tahun 2013 yaitu sebesar $35,40 \%$. Berdasarkan hasil analisis memperlihatkan bahwa penilaian kinerja dengan metode analisis rasio keuangan menghasilkan nilai yang cukup signifikan. Selain itu dengan menggunakan metode analisis rasio keuangan para pemimpin perusahaan dapat mengetahui kinerja keuangan tersebut. Hal ini karena analisis rasio keuangan dapat menilai keadaan perusahaan pada saat yang membuat perusahaan lebih memperhatikan efektivitas modal sehingga dapat mengidentifikasikan kegiatan yang memberikan pengembalian lebih tinggi dari pada modal.

\section{Simpulan Dan Saran}

\subsection{Simpulan}

Berdasarkan keterangan dan pembahasan dari bab-bab sebelumnya maka diambil kesimpulan sebagai berikut:

1. Secara umum rasio likuiditas menunjukkan hasil yang positif karena hampir semua rasionya lebih dari satu, sehingga mudah bagi perusahaan untuk melunasi hutang jangka pendeknya. Jika dilihat dari current ratio dapat diketahui pada tahun 2013 current ratio sebesar 104,92\%, pada tahun 2014 current ratio meningkat menjadi 505,92\%, pada tahun 2015 current ratio turun menjadi 481,18\%, dan pada tahun 2016 current ratio kembali turun menjadi 306,02\%. Rasio seperti ini sangat baik bagi posisi keuangan perusahaan, namun kurang efisien karena masih banyak aktiva yang tidak digunakan.

2. Dilihat dari rasio solvabilitas PT. Sinar Roda Utama mengalami masa baik pada tahun 2014 dimana perbandingan hutang dengan aktiva ataupun hutang dengan modal sangat sangat kecil, yaitu sebesar 66,88\% untuk Debt To Assetss Ratio, hal ini menunjukkan bahwa pada tahun tersebut nilai aktiva lebih besar daripada utang dan 201,97\% untuk Debt To Equity Ratio. Pada tahun-tahun berikutnya rasio hutang perusahaan mulai meninggi tapi masih berada ditingkat yang bagus. Sehingga berdasarkan data tersebut di atas, kinerja keuangan PT. Sinar Roda Utama dalam keadaan kurang baik.

3. Dilihat dari rasio profitabilitas PT. Sinar Roda Utama dalam keadaan yang baik karena dari tahun 2013-2016 profit yang dihasilkan terus meningkat. Sehingga berdasarkan data tersebut di atas, kinerja keuangan PT. Sinar Roda Utama dalam keadaan baik.

4. PT. Sinar Roda Utama menunjukkan performance yang baik untuk mencapai tujuan perusahaan. Pada tahun 2014 PT. Sinar Roda Utama mengalami masa yang baik, dimana rasio hutang kecil, namun pada 2 tahun terakhir menunjukkan kondisi yang kurang baik dengan mulai meningkatnya rasio hutang, namun kinerja keuangan perusahaan masih dalam keadaan yang baik.

\subsection{Saran}

Hasil penelitian yang penulis peroleh seperti diuraikan dalam temuan, mendasari penulis untuk mengajukan saran seperti berikut:

1. Bagi Perusahaan

Perusahaan hendaknya memanfaatkan aktiva dan mengurangi hutang agar menjadi proporsi yang baik. Hal ini perlu dilakukan mengingat rasio profitabilats yang cukup dari standar industri. Selain itu pemanfaatan aktiva perlu dilakukan untuk menghindari adanya aktiva yang 
menganggur, yang mengakibatkan perusahaan harus menanggung Opportunity Cost (biaya kehilangan kesempatan mendapatkan keuntungan) yang relatif tinggi. Perusahaan harus mampu meningkatkan volume penjualan dengan skala besar dengan tujuan untuk meningkatkan jumlah pendapatan yang akan berimbas pada peningkatan laba (profit) perusahaan.

2. Bagi Peneliti Selanjutnya

Untuk pihak yang berkepentingan, sebaiknya lebih hati-hati dalam menilai kinerja keuangan jangan sampai tertipu oleh laba besar yang dimiliki namun juga harus memperhatikan tingkat resiko.

\section{Daftar Pustaka}

Anoraga, Pandji. 2004. Manajemen Bisnis Cetakan Ketiga. Penerbit Rineka Cipta. Jakarta.

Albertus Karjono. 2009. Kinerja Keuangan Perusahaan dari Tingkat Likuiditas, Solvabilitas, Profitabilitas, dan Aktivitas. Penerbit Institut Bisnis Nusantara. Jakarta.

Astuti, Dewi. 2002. Manajemen Keuangan Perusahaan. Penerbit Rineka Cipta Jakarta.

Bastian, Indra. 2007. Audit Sektor Publik. Penerbit Salemba Empat. Jakarta.

Belkaoui, Ahmed Riahi. 2010. Teori Akuntansi. Penerbit Salemba Empat. Jakarta.

Halim, Abdul dan Theresia. 2007. Manajemen Keuangan Daerah Pengelolaan Keuangan Daerah. Penerbit UPP STIM YKPN. Yogyakarta.

Hanafi, Mamduh dan A. Halim. 2007. Analisis Laporan Keuangan. Penerbit UPP STIM YKPN. Yogyakarta.

Hanafi, Muhammad Mamduh dan Halim, Abdul. 2012. Analisis Laporan Keuangan. Penerbit UPP Sekolah Tinggi Ilmu Manajemen YKPN. Yogyakarta.

Harahap, Sofyan Syafri. 2012. Anaslisis Kritis Atas Laporan Keuangan. Penerbit PT. Grafindo Persada. Jakarta.

2011. Teori Akuntansi. Penerbit Raja Grafindo Persada. Jakarta.

Hernawati, Anjani. 2010. Likuiditas, Solvabilitas dan Rentabilitas Kinerja Keuangan PT. Madu Baru Periode 2007-2008. Jurnal UUP STIM YKPN Vol. 1 No.1. Penerbit UPP STIM YKPN. Yogyakarta.

Jumingan. 2006. Analisa Laporan Keuangan. Penerbit PT. Grafindo Persada. Jakarta.

Jusup, Haryono. 2011. Dasar-dasar Akuntansi. Penerbit Sekolah Tinggi Ilmu Ekonomi YKPN. Yogyakarta.

Kasmir. 2009. Analisis Laporan Keuangan. Penerbit Raja Grafindo Persada. Jakarta.

Kieso. 2009. Akuntansi Menengah. Penerbit Raja Grafindo Persada. Jakarta.

Munawir, S. 2004. Analisa Laporan Keuangan. Penerbit Liberty. Yogyakarta.

Muqorobin, Agus. 2009. Penerapan Rasio Keuangan Pada Pengelolaan Dana KUD Banyudono Selatan. Jurnal Keuangan Vol. 6 No. 1. Penerbit Universitas Airlangga. Surabaya.

Nazir, Mohamad. 2011. Metode Penelitian. Penerbit Ghalia Indonesia. Bogor.

Nurfitriani. 2005. Manajemen Keuangan. Penerbit UPP AMP YKPN. Yogyakarta.

Rahardjo, Budi. 2002. Akuntansi dan Keuangan Untuk Manajer Non Keuangan. Penerbit Graha Ilmu. Yogyakarta.

Rudianto. 2006. Akuntansi Manajemen. Penerbit PT. Grasindo. Jakarta.

Sariningsih, Dwi. 2009. Analisis Kinerja Keuangan di Tinjau dari Rasio Likuiditas, Solvabilitas dan Rasio Profitabilitas Pada CV Lembu Mada Nusantara di Samarinda. Jurnal Akuntansi Vol. 1 No. 1. Penerbit Universitas Lambung Mangkurat. Samarinda.

Sawir, Agnes. 2013. Analisa Kinerja Keuangan dan Perencanaan Keuangan Perusahaan. Penerbit PT. Gramedia Pustaka Utama. Jakarta.

Soemarso. 2009. Akuntansi Suatu Pengantar. Penerbit Salemba Empat. Jakarta. 
Sugiono, Arief dan Untung, Edi. 2008. Panduan Praktis Dasar Analisa Laporan Keuangan. Penerbit Grasindo. Jakarta.

Sugiyono. 2012. Metode Penelitian. Penerbit Alfabeta. Bandung.

Sujoko, Efferin. 2008. Metode Penelitian Akuntansi Mengungkap Fenomena dengan Pendekatan Kuantitatif dan Kualitatif. Penerbit Graha Ilmu. Yogyakarta.

Sutrisno. 2009. Manajemen Keuangan Teori, Konsep, dan Aplikasi. Penerbit Ekonisia. Yogyakarta.

Syamsuddin, Lukman. 2001. Manajemen Keuangan Perusahaan. PT. Raja Grafindo Persada. Jakarta.

www.idx.co.id (diakses pada tanggal 23 April 2017) 